\title{
Probing hidden diversity to enhance conservation of the endangered narrow-range endemic Eastern Cape rocky, Sandelia bainsii (Castelnau 1861)
}

\begin{tabular}{|c|c|}
\hline \multicolumn{2}{|c|}{$\begin{array}{l}\text { Authors: } \\
\text { Albert Chakona } 1,2 \\
\text { Gavin Gouws }^{1,2} \\
\text { Wilbert T. Kadye }^{2} \\
\text { Pule P. Mpopetsi } \\
\text { Paul H. Skelton } \\
\text { Pa }\end{array}$} \\
\hline \multicolumn{2}{|c|}{$\begin{array}{l}\text { Affiliations: } \\
{ }^{1} \text { National Research } \\
\text { Foundation - South African } \\
\text { Institute for Aquatic } \\
\text { Biodiversity, Grahamstown, } \\
\text { South Africa }\end{array}$} \\
\hline \multicolumn{2}{|c|}{$\begin{array}{l}{ }^{2} \text { Department of Ichthyology } \\
\text { and Fisheries Science, Rhodes } \\
\text { University, Grahamstown, } \\
\text { South Africa }\end{array}$} \\
\hline \multicolumn{2}{|c|}{$\begin{array}{l}\text { Corresponding author: } \\
\text { Albert Chakona, } \\
\text { a.chakona@saiab.ac.za }\end{array}$} \\
\hline \multicolumn{2}{|c|}{$\begin{array}{l}\text { Dates: } \\
\text { Received: } 03 \text { Mar. } 2020 \\
\text { Accepted: } 22 \text { July } 2020 \\
\text { Published: } 29 \text { Sept. } 2020\end{array}$} \\
\hline \multicolumn{2}{|c|}{$\begin{array}{l}\text { How to cite this article: } \\
\text { Chakona, A., Gouws, G., } \\
\text { Kadye, W.T., Mpopetsi, P.P. \& } \\
\text { Skelton, P.H., 2020, 'Probing } \\
\text { hidden diversity to enhance } \\
\text { conservation of the } \\
\text { endangered narrow-range } \\
\text { endemic Eastern Cape rocky, } \\
\text { Sandelia bainsii (Castelnau } \\
\text { 1861)', Koedoe 62(1), a1627. } \\
\text { https://doi.org/10.4102/ } \\
\text { koedoe.v62i1.1627 }\end{array}$} \\
\hline \multicolumn{2}{|c|}{$\begin{array}{l}\text { Copyright: } \\
\text { (C) 2020. The Authors. } \\
\text { Licensee: AOSIS. This } \\
\text { is licensed under the } \\
\text { Creative Commons } \\
\text { Attribution License. }\end{array}$} \\
\hline \multicolumn{2}{|l|}{ Read online: } \\
\hline $\begin{array}{l}\text { arg } \\
\text { atsis }\end{array}$ & $\begin{array}{l}\text { Scan this QR } \\
\text { code with your } \\
\text { smart phone or } \\
\text { mobile device } \\
\text { to read online. }\end{array}$ \\
\hline
\end{tabular}

\section{Introduction}

Accurate delimitation of species boundaries is a fundamental requirement for formulating environmental policies and spatial conservation planning to prevent loss of biodiversity (e.g. $\mathrm{Nel}$ et al. 2011). However, because morphological differences may remain undetected as a result of their subtlelty and the experience or expertise of the observer, there are several cases where two or more morphologically similar species have been mistakenly classified into a single taxon, thus compromising conservation of rare, cryptic and narrow-range species (Bickford et al. 2007). The use of molecular data has resulted in the discovery of new species and several historically isolated lineages within many groups of freshwater fishes that were previously considered to be single wide-ranging species. This is particularly true for the Cape Fold freshwater ecoregion (CFE) in South Africa and the Eastern Zimbabwe Highlands freshwater ecoregion (EZH), where new species, unique lineages and taxonomic conflicts have been discovered in various species groups (e.g. Bronaugh, Swartz \& Sidlauskas 2020; Chakona et al. 2018a; Chakona, Swartz \& Gouws 2013; Swartz, Skelton \& Bloomer 2009; Wishart et al. 2006). Such findings have stimulated renewed interest in the systematics and taxonomic revisions of freshwater fishes in southern Africa (e.g. Chakona \& Skelton 2017; Chakona \& Swartz 2013; Chakona, Swartz \& Skelton 2014; Maake, Gon \& Swartz 2014). This information has also been critical in guiding accurate International Union for Conservation of Nature (IUCN) redlist assessments for freshwater fishes in South Africa (Chakona et al. in prep).

In the present study, mitochondrial $16 \mathrm{~S}$ ribosomal ribonucleic acid (rRNA) sequences were used to explore patterns of spatial genetic structuring in the Eastern Cape rocky, Sandelia bainsii, with the aim of illuminating the implications of incomplete systematic knowledge on the conservation of aquatic biodiversity. The Eastern Cape rocky attains the largest size of all anabantid species, reaching a standard length of about $260 \mathrm{~mm}$ (Skelton 2001). This species is endemic to South Africa, where it has a restricted distribution, occurring in short sections of the Kowie, Great Fish, Keiskamma, Igoda, Buffalo and Nahoon river systems in the Eastern Cape Province (Skelton 2001; Figure 1). The species is listed by the IUCN as endangered, and the persistence of remnant populations is uncertain as a result of deterioration in water and habitat quality, the spread of non-native piscivores, habitat fragmentation and hydrological modifications (Chakona, Sifundza \& Kadye 2018b; Figure 1). Many of the known remnant populations of this species are highly fragmented, and there are concerns that some of these populations may not be viable in the long term (Chakona et al. 2018a).

A previous genetic study based on mitochondrial cytochrome $b$ data provided the first evidence for the existence of historically isolated lineages within the Eastern Cape rocky (Roos 2005). This raised concerns that these lineages could be facing a higher risk of extinction as they may potentially have narrower geographic ranges than currently recognised for this species. However, as a result of the small sample sizes and large geographic sampling gaps, this study could not provide a clear determination of the number of lineages and their distribution ranges. The present study builds on the findings of Roos (2005), by collecting samples from all known extant populations of the Eastern Cape rocky to (1) determine the number of unique lineages within this species and (2) provide more accurate distribution ranges of the lineages. We discuss critical future research directions and conservation options to ensure the long-term persistence of the lineages identified within the Eastern Cape rocky. 


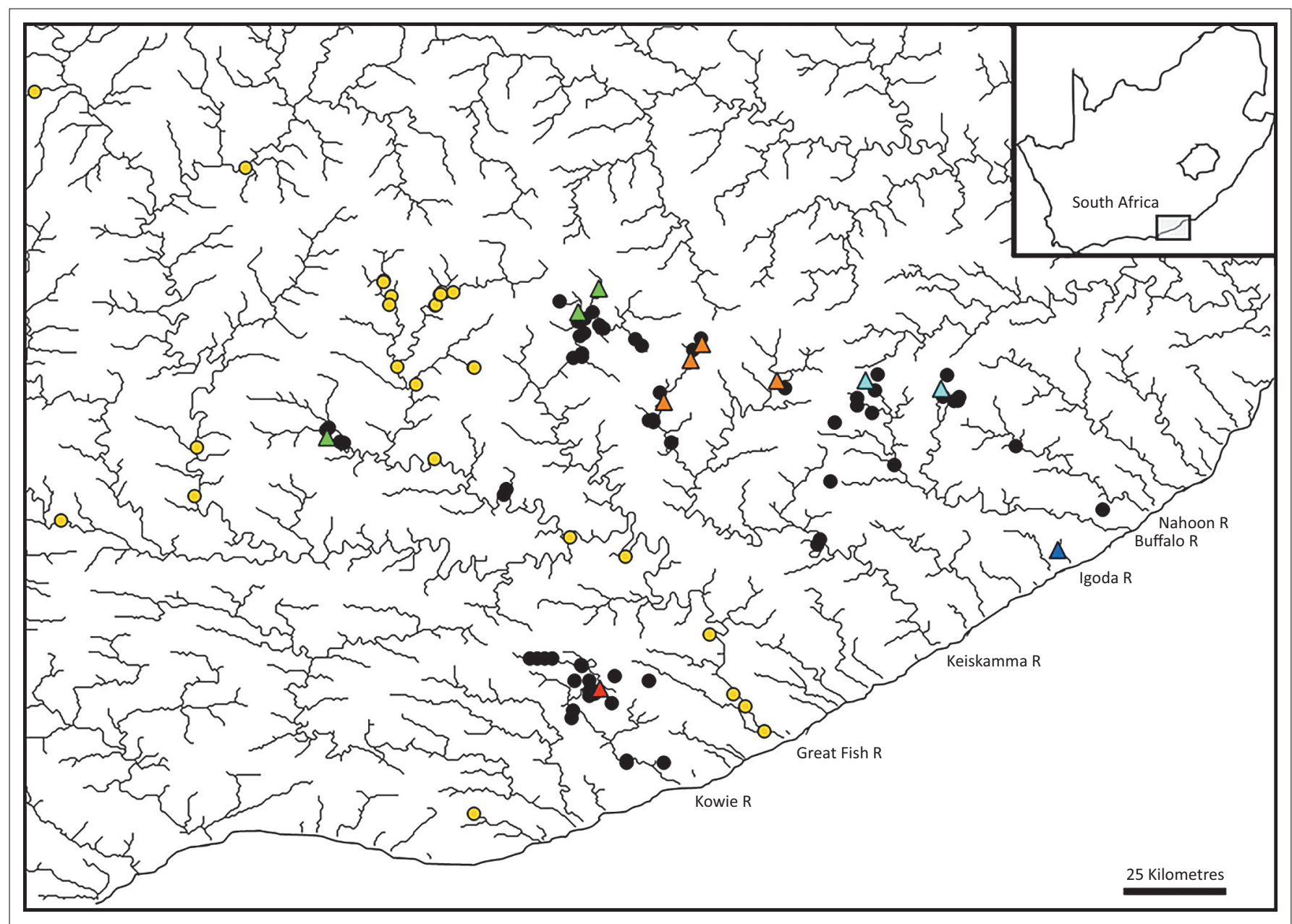

NRF, National Research Foundation; SAIAB, South African Institute for Aquatic Biodiversity.

FIGURE 1: Historical distribution of the Eastern Cape rocky, Sandelia bainsii, based on records from the National Fish Collection at the NRF-SAIAB (black circles), the localities where tissues samples were collected from the Kowie (red triangle), Great Fish (green triangles), Keiskamma (orange triangles), Igoda (turquoise triangle) and Buffalo (navy blue triangles) river systems. The yellow points represent localities where Sandelia bainsii was not recorded from recent surveys (2009-2014).

\section{Materials and methods \\ Sample collection}

The present study used data that were collected between 2010 and 2017. The samples were collected from 11 localities in the Kowie, Great Fish, Keiskamma, Igoda and Nahoon river systems, representing all the known remnant populations of S. bainsii (Table 1; Figure 1). Sampling was done using fyke nets, seine nets and electric fishing. Because $S$. bainsii is a threatened species, only fin clips were collected for the present study, and all sampled fish were returned to their habitat alive.

\section{Deoxyribonucleic acid extraction, amplification and sequencing}

Laboratory work and sequencing were conducted at the Aquatic Genomic Research Platform, NRF-South African Institute for Aquatic Biodiversity (SAIAB). Deoxyribonucleic acid (DNA) was extracted from 21 fin clip samples using the salting-out method (Sunnucks \& Hales 1996). A fragment of the mitochondrial 16S rRNA gene was amplified using the primer pair 16Sar and 16Sbr (Palumbi, 1996 ) and sequenced using the forward primer (16Sar). Each
PCR mixture $(25 \mu \mathrm{L})$ contained $1 \times$ buffer, $2.5 \mathrm{mM} \mathrm{MgCl}{ }_{2^{\prime}}$ $0.8 \mathrm{mM}$ deoxyribonucleotide triphosphates (dNTPs), $0.2 \mu \mathrm{M}$ of each primer and $0.5 \mathrm{U}$ Taq polymerase and DNA template (final concentration, $4.3 \mathrm{ng} / \mu \mathrm{L}-9.5 \mathrm{ng} / \mu \mathrm{L}$ ). The reaction volume was adjusted with $\mathrm{dH}_{2} \mathrm{O}$ to a final volume of $25 \mu \mathrm{L}$, depending on the volume of the DNA template used. The amplification profile was initial denaturing at $95^{\circ} \mathrm{C}$ for $3 \mathrm{~min}$, followed by 35 cycles of denaturing at $95^{\circ} \mathrm{C}$ for $50 \mathrm{~s}$, annealing at $50{ }^{\circ} \mathrm{C}$ for $30 \mathrm{~s}$ and extension at $72{ }^{\circ} \mathrm{C}$ for $50 \mathrm{~s}$. The reaction was then completed by a final extension at $72{ }^{\circ} \mathrm{C}$ for $10 \mathrm{~min}$. The products were purified using an ExoSAP method (ThermoFisher Scientific). The purified products were then cycle sequenced using ABI (Applied Biosystems, Austin, Texas) Big Dye version 3.1 cycle sequencing. Sequencing was done using an ABI Hitachi 3500 genetic analyser at the NRFSAIAB.

\section{Data analysis}

The sequences were assembled and manually edited to equal lengths using SEQMAN version 7.2.1 (DNA STAR Lasergene Segman Pro) and then aligned in Clustal X2 (Larkin et al. 2007). jModeltest (Darriba et al. 2012) was used to select the best-fit model of nucleotide evolution based on the Akaike information 
TABLE 1: Sequence numbers and locality details for the lineages identified within Sandelia bainsii.

\begin{tabular}{|c|c|c|c|c|c|c|}
\hline Date & River system & Latitude & Longitude & SAIAB sequence no. & GenBank accession no. & Lineage name \\
\hline $18 / 8 / 2015$ & Igoda & -33.0736 & 27.7497 & SB1133 & МT990986 & Sandelia sp. 'bainsii Buffalo' \\
\hline $18 / 8 / 2015$ & Igoda & -33.0736 & 27.7497 & SB1134 & MT990987 & Sandelia sp. 'bainsii Buffalo' \\
\hline $18 / 8 / 2015$ & Igoda & -33.0736 & 27.7497 & SB1135 & MT990988 & Sandelia sp. 'bainsii Buffalo' \\
\hline $18 / 8 / 2015$ & Igoda & -33.0736 & 27.7497 & SB1136 & MT990989 & Sandelia sp. 'bainsii Buffalo' \\
\hline $18 / 8 / 2015$ & Igoda & -33.0736 & 27.7497 & SB1137 & Мт990990 & Sandelia sp. 'bainsii Buffalo' \\
\hline $17 / 8 / 2015$ & Buffalo & -32.6937 & 27.3188 & SB1138 & Мт990991 & Sandelia sp. 'bainsii Buffalo' \\
\hline $19 / 8 / 2015$ & Buffalo & -32.7123 & 27.4879 & SB1139 & Мт990992 & Sandelia sp. 'bainsii Buffalo' \\
\hline $19 / 8 / 2015$ & Buffalo & -32.7123 & 27.4879 & SB1140 & Мт990993 & Sandelia sp. 'bainsii Buffalo' \\
\hline $19 / 8 / 2015$ & Buffalo & -32.7123 & 27.4879 & SB1142 & MT990994 & Sandelia sp. 'bainsii Buffalo' \\
\hline $19 / 8 / 2010$ & Keiskamma & -32.6943 & 27.1202 & SB1116 & Мт990985 & Sandelia sp. 'bainsii Keiskamma' \\
\hline $19 / 8 / 2010$ & Keiskamma & -32.7418 & 26.8668 & SB1151 & Мт990995 & Sandelia sp. 'bainsii Keiskamma' \\
\hline $19 / 8 / 2010$ & Keiskamma & -32.6943 & 27.1202 & SB1152 & Мт990996 & Sandelia sp. 'bainsii Keiskamma' \\
\hline $19 / 8 / 2010$ & Keiskamma & -32.6121 & 26.9523 & SB1153 & МT990997 & Sandelia sp. 'bainsii Keiskamma' \\
\hline $19 / 8 / 2010$ & Keiskamma & -32.648 & 26.9268 & SB1154 & МT990998 & Sandelia sp. 'bainsii Keiskamma' \\
\hline $21 / 2 / 2014$ & Kowie & -33.384 & 26.7236 & SB1158 & МT991000 & Sandelia sp. 'bainsii Kowie' \\
\hline $21 / 2 / 2014$ & Kowie & -33.384 & 26.7236 & SB1159 & MT991001 & Sandelia sp. 'bainsii Kowie' \\
\hline $21 / 8 / 2015$ & Great Fish & -32.8211 & 26.1121 & SB1187 & MT991002 & Sandelia sp. 'bainsii Kowie' \\
\hline $21 / 8 / 2015$ & Great Fish & -32.8211 & 26.1121 & SB1188 & MT991003 & Sandelia sp. 'bainsii Kowie' \\
\hline $21 / 8 / 2015$ & Great Fish & -32.4876 & 26.7212 & SB1190 & MT991004 & Sandelia sp. 'bainsii Kowie' \\
\hline $21 / 8 / 2015$ & Great Fish & -32.5409 & 26.6749 & SB1191 & MT991005 & Sandelia sp. 'bainsii Kowie' \\
\hline
\end{tabular}

NRF, National Research Foundation; SAIAB, South African Institute for Aquatic Biodiversity.

criterion (AIC) as implemented on the CIPRES Science Gateway (Miller, Pfeiffer \& Schwartz 2010). A maximum likelihood (ML) tree was generated using RAxML version 8.2.6 (Stamatakis 2014), performed on the CIPRES Science Gateway (Miller et al. 2010). Sandelia capensis, Ctenopoma kingsleyae, Ctenopoma patherici and Ctenopoma occelatum were used as outgroups. To further assess the genealogical relationships between sequences among the populations of S. bainsii, a haplotype network was generated using the statistical parsimony method implemented in the program TCS (Clement Posada \& Crandall 2000). We used PAUP* (Swofford 2002) to estimate the model-corrected genetic distances using the Three Parameter Model (TPM2uf+I) (Kimura, 1981) model of nucleotide evolution.

\section{Results and discussion}

The edited alignment of 21 mitochondrial DNA (mtDNA) $16 \mathrm{~S}$ sequences was $439 \mathrm{bp}$ in length with 13 polymorphic sites that defined four unique haplotypes (Figure 2). The TPM2uf + I (Kimura 1981) was selected as the best model of sequence evolution. The ML tree and the Templeton, Crandall and Sing (TCS) haplotype network revealed strong geographic structuring within S. bainsii, with the sequences split into three distinct lineages (Figure 2). These lineages are herein referred to as Sandelia sp. 'bainsii Kowie', which is confined to the Kowie and Great Fish river systems, Sandelia sp. 'bainsii Keiskamma', which is confined to the Keiskamma River system and Sandelia sp. 'bainsii Buffalo', which occurs in the Buffalo and Igoda river systems (Figure 2). These findings are consistent with those of Roos (2005), who identified two lineages corresponding to Sandelia sp. 'bainsii Kowie' and Sandelia sp. 'bainsii Buffalo'. However, Roos' (2005) study did not include samples from the Keiskamma River system. All samples from the Kowie and Great Fish river systems comprised a single haplotype (Figure 2), suggesting that this lineage could have experienced recent range expansion, possibly because of human-mediated translocation, palaeodrainage connections, river captures or intermittent connection of low-drainage divides as inferred for other stream fishes in the genera Galaxias, Pseudobarbus and Sandelia in the CFE (Bronaugh et al. 2020; Chakona et al. 2013; Swartz et al., 2009). Similarly, the sharing of a haplotype between the Buffalo and Igoda river systems also suggests recent connectivity or range expansion between these systems. The existence of these geographically isolated lineages clearly indicates the need for studies that, for example, use multiple genetic markers to determine the patterns of gene flow and investigate the ecology and population dynamics for each lineage. This would provide a better understanding of the mechanisms that have shaped the evolutionary history of S. bainsii sensu lato, as well as inform revision of the freshwater fish sanctuaries in South Africa (Nel et al. 2011).

The low haplotype diversity observed in the present study suggests that population decline (Cambray 1996) could have reduced genetic diversity within the Eastern Cape rocky. Advances in molecular techniques that allow extraction and sequencing of DNA from formalin-preserved specimens would provide an opportunity to leverage sequence data from old historical specimens to investigate changes in genetic diversity over time and the possibility of uncovering species or lineages that are now extinct in the wild (Ruane \& Austin 2017). The existence of comprehensive samples of $S$. bainsii within the NRF-SAIAB National Fish Collection facility offers a unique opportunity for future studies to investigate the changes in the genetic diversity of the Eastern Cape rocky over time and identify possible causes for those changes. 


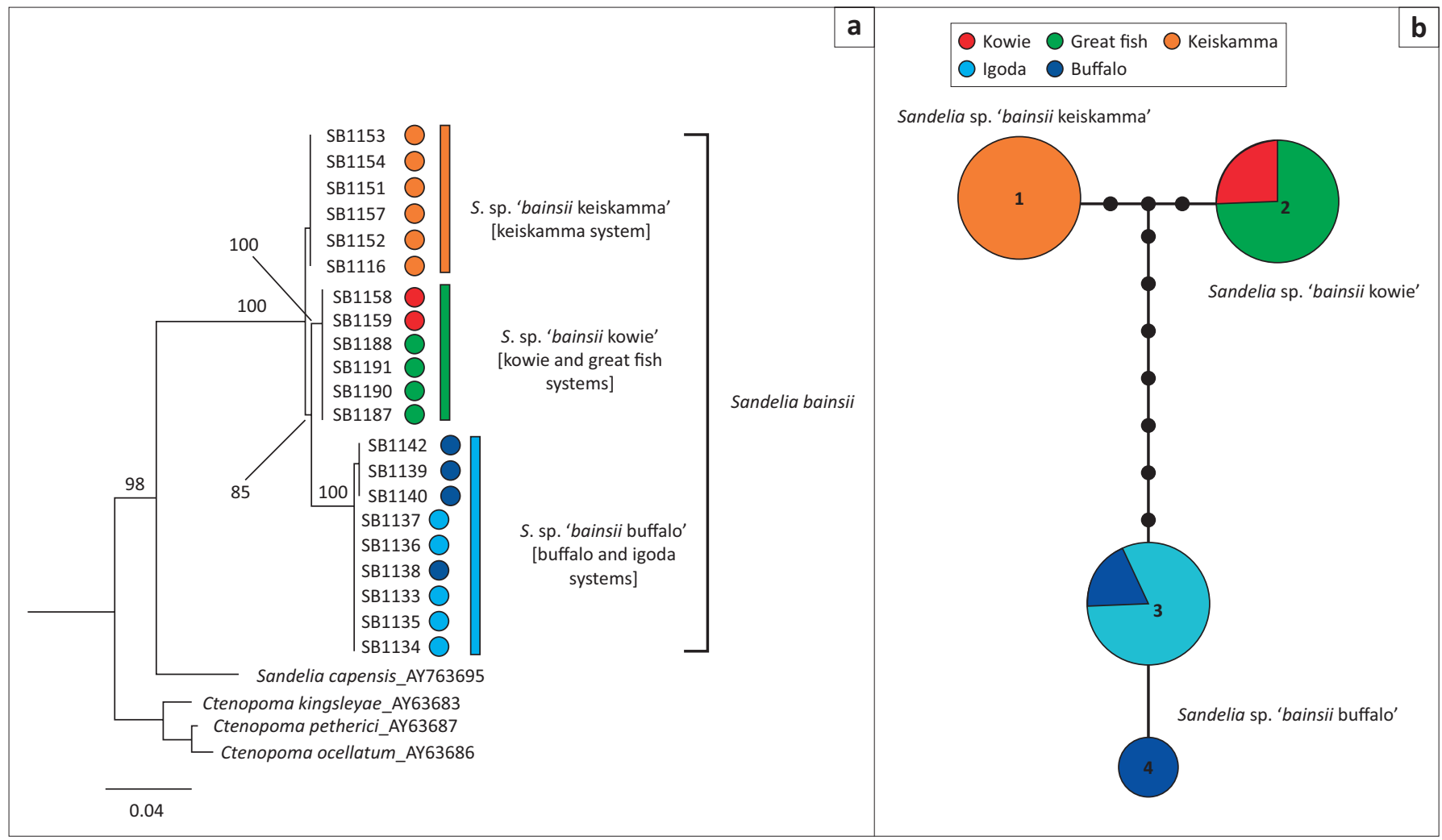

FIGURE 2: Maximum likelihood phylogeny (a) and TCS haplotype network (b) showing the existence of three lineages (Sandelia sp. 'bainsii Kowie', Sandelia sp. 'bainsi Keiskamma' and Sandelia sp. 'bainsii Buffalo') within the Eastern Cape rocky, Sandelia bainsii. The river systems where each of these lineages were recorded are indicated.

TABLE 2: Mitochondrial 16S ribosomal ribonucleic acid sequence divergence estimates (\%) among the three lineages identified within the Eastern Cape rocky, Sandelia sp. 'bainsii Kowie', Sandelia sp. 'bainsii Keiskamma' and Sandelia sp. 'bainsii Buffalo'

\begin{tabular}{llcccc}
\hline Code & Lineage/species & $\mathbf{1}$ & $\mathbf{2}$ & $\mathbf{3}$ & $\mathbf{4}$ \\
\hline 1 & Sandelia sp. 'bainsii Kowie' & 0.0 & - & - & - \\
2 & Sandelia sp. 'bainsii Keiskamma' & 0.95 & 0.0 & - & - \\
3 & Sandelia sp. 'bainsii buffalo' & $2.42-2.68$ & $2.47-2.73$ & - & - \\
4 & Ctenopoma petherici & 14.63 & 14.16 & $16.58-17.01$ & - \\
5 & Ctenopoma ocellatum & 11.334 & 14.54 & $17.10-17.56$ & - \\
6 & Ctenopoma kingsleye & 13.77 & 13.34 & 1.18 & - \\
\hline
\end{tabular}

Divergences among species of the anabantid genus Ctenopoma are presented for comparison.

RNA, ribonucleic acid.

The range of genetic divergence values between Sandelia sp. 'bainsii Kowie' and Sandelia sp. 'bainsii Buffalo' (2.42\% - 2.73\%) is consistent with that found for interspecific mtDNA sequence divergences in a number of fish genera (Ward 2009) and was also comparable to interspecific differences among some species in the genus Ctenopoma (see Table 2), which is the sister genus to Sandelia (Rüber, Britz \& Zardoya 2006). Our results highlight the need for further studies that integrate genetic (both mitochondrial and nuclear sequences), morphological, osteological, ecological and other biological characteristics (e.g. Puillandre et al. 2012) to determine the taxonomic status of the lineages identified within S. bainsii. A recent study by Bronaugh et al. (2019) also revealed the existence of at least three deeply divergent lineages and substantial intralineage genetic and geographic structuring within S. capensis, indicating that the current taxonomy obscures the diversity of these anabantid fishes that are endemic to the CFE of South Africa.

Sandelia bainsii was described by Castelnau (1861) based on samples that were collected from the Kowie River system.
In the same year, Günther (1861) described another species, Ctenopoma microlepidotum, with the type locality details of the holotype vaguely presented as 'freshwaters of the Cape of Good Hope, South Africa'. This species was subsequently synonymised with S. bainsii (Skelton 2018). Morphological examination of the types of S. bainsii and C. microlepidotum is currently ongoing to determine whether they are conspecific and to evaluate whether Sandelia sp. 'bainsii Kowie', Sandelia sp. 'bainsii Keiskamma' and Sandelia sp. 'bainsii Buffalo' constitute distinct taxonomic entities.

The discovery of three genetically distinct and historically isolated lineages within the Eastern Cape rocky, which is already listed as endangered by the IUCN (Chakona et al. $2018 b$ ), supports the growing need to expedite discovery and documentation of biodiversity because the existence of hidden diversity in many taxa hampers conservation efforts (e.g. Bickford et al. 2007). As recommended by Moritz (1994), to preserve the evolutionary processes that shaped the genetic patterns within $S$. bainsii, the three lineages need to be 
managed separately. This requires close collaboration between researchers, conservationists and local stakeholders (landowners) to develop a sustainable partnership programme that will promote improved catchment management practices for sustainable ecological functioning of the rivers and to protect critical habitats for these lineages.

Previous and ongoing field surveys have reported significant declines in the historical distribution range of S. bainsii, with the population in the Kowie River system feared to be nearing extinction, as only two specimens were recorded from comprehensive surveys that were conducted between 2010 and 2017 (Figure 1). The Eastern Cape rocky appears to be highly sensitive to poor water quality, as it has not been recorded from heavily polluted sections of the Kowie and Bloukranz rivers where it was historically abundant. All remnant populations of S. bainsii are highly fragmented, because they are isolated by instream impoundments and invasion of the mainstem sections of the rivers by non-native fishes, which may prevent connectivity and hamper gene flow. Field observations suggest that most of these remnant populations are likely to be represented by small population sizes, as they were only recorded in short stretches of the streams where they were found. Empirical data show that population fragmentation leads to rapid deterioration in genetic diversity in small populations because of genetic drift and inbreeding (Bessert \& Ortí 2008; Pavlova et al. 2017). As genetic diversity underpins the ability of populations to persist and adapt to environmental changes (Hughes, Schmidt \& Finn 2009), there are concerns that the small isolated populations of Sandelia sp. 'bainsii Kowie', Sandelia sp. 'bainsii Keiskamma' and Sandelia sp. 'bainsii Buffalo' could be at high risk of extinction as a result of the possibility of inbreeding depression, loss of fitness and reduced adaptive potential. Future studies should focus on assessing the implications of population fragmentation on genetic diversity and the evolutionary potential of each of these newly identified lineages. In addition, studies should determine effective conservation strategies, such as securing remnant populations to prevent invasion by non-native fishes, rehabilitation of degraded habitats and genetic rescue through assisted gene flow (see Pavlova et al. 2017), where such measures are deemed necessary interventions.

\section{Acknowledgements}

The authors hereby acknowledge the use of the equipment provided by the NRF-SAIAB Molecular Genetic Laboratory and the NRF-SAIAB Collection Management Centre. Greg Brett from East London Museum, Leah Sloman, Apelele Zonda and Bosupeng Motshegoa are thanked for their assistance with fieldwork; Leah Sloman for generating the sequences.

\section{Competing interests}

The authors have declared that no competing interests exist.

\section{Authors' contributions}

This work formed part of P.P.M.'s Hons project; A.C. secured research funding; A.C. and P.H.S. conceived the research; A.C., P.P.M. and W.T.K. conducted the fieldwork; A.C. and G.G. performed the genetic analyses. All authors contributed equally to writing and revising the manuscript.

\section{Ethical consideration}

This research was carried out following the evaluation and approval of the sampling protocols by the National Research Foundation - South African Institute for Aquatic Biodiversity Animal Ethics Committee (reference 2014/03). Permits to carry out this research were obtained from the Department of Economic Development, Environmental Affairs and Tourism (Eastern Cape Province) (permit numbers CRO 88/15CR and CRO 44/18CR).

\section{Funding information}

This work was supported by the National Research Foundation (NRF) of South Africa under the Foundational Biodiversity Information Programme (FBIP) through Biodiversity Surveys in Priority Inland Areas (IBIP) grant (grant no. IBIP-BS13100251309) through a joint initiative with the Department of Science of Technology, the NRF and the South African National Biodiversity Institute.

\section{Data availability statement}

The sequences generated from this study were submitted to GenBank.

\section{Disclaimer}

The authors acknowledge that the opinions, findings and conclusions or recommendations expressed in this publication generated by NRF-supported research belong to the authors and that the NRF accepts no liability whatsoever in this regard.

\section{References}

Bessert, M.L. \& Ortí, G., 2008, 'Genetic effects of habitat fragmentation on blue sucker populations in the upper Missouri River (Cycleptus elongatus Lesueur, 1918)', Conservation Genetics 9, 821-832. https://doi.org/10.1007/s10592-007-9401-4

Bickford, D., Lohman, D.J., Navjot, S.S., Ng, P.K.L., Meier, R., Winker, K. et al., 2007, 'Cryptic species as a window on diversity and conservation', Trends in Ecology and Evolution 22(3), 148-155. https://doi.org/10.1016/j.tree.2006.11.004

Bronaugh, W.M., Swartz, E.R. \& Sidlauskas, B.L., 2020, 'Between an ocean and a high place: Coastal drainage isolation generates endemic cryptic species in the Cape kurper Sandelia capensis (Anabantiformes: Anabantidae), Cape Region, South Africa', Journal of Fish Biology 96(5), 1087-1099. https://doi.org/10.1111/jfb.14182

Cambray, J.A., 1996, 'Threatened fishes of the world: Sandelia bainsii Castelnau, 1861 (Anabantidae)', Environmental Biology of Fishes 1(3), 159-168.

Chakona, A. \& Skelton, P.H., 2017, 'A review of the Pseudobarbus afer (Peters 1864) species complex (Teleostei, Cyprinidae) in the eastern Cape Fold Ecoregion of South Africa', ZooKeys 657, 109-140. https://doi.org/10.3897/zookeys.657.11076

Chakona, A. \& Swartz, E.R., 2013, 'A new redfin species, Pseudobarbus skelton (Cyprinidae, Teleostei), from the Cape Floristic Region, South Africa', Zootaxa 3686(5), 565-577. https://doi.org/10.11646/zootaxa.3686.5.5

Chakona, A., Kadye, W.T., Bere, T., Mazungula, D.N. \& Vreven, E., 2018a, 'Evidence of hidden diversity and taxonomic conflicts in five stream fishes from the Eastern Zimbabwe Highlands freshwater ecoregion', ZooKeys 768, 69-95. https://doi. org/10.3897/zookeys.768.21944 
Chakona, A., Sifundza, D. \& Kadye, W.T., 2018b, 'Sandelia bainsii, The IUCN red list of threatened species 2018, e.T19889A99447325', https://doi.org/10.2305/IUCN. threatened species 2018, e.T19889A
UK.2018-1.RLTS.T19889A99447325.en

Chakona, A., Swartz, E.R. \& Gouws, G., 2013, 'Evolutionary drivers of diversification and distribution of a southern temperate stream fish assemblage: Testing the role of historical isolation and spatial range expansion', PLoS One 8(8), e70953. https:// doi.org/10.1371/journal.pone.0070953

Chakona, A., Swartz, E.R. \& Skelton, P.H., 2014, 'A new species of redfin (Teleostei, Cyprinidae, Pseudobarbus) from the Verlorenvlei River system, South Africa', ZooKeys 453, 121-137. https://doi.org/10.3897/zookeys.453.8072

Clement, M., Posada, D. \& Crandall, K.A., 2000, 'TCS: A computer program to estimate gene genealogies', Molecular Ecology 9(10), 1657-1659. https://doi.org/10.1046/ j.1365-294x.2000.01020.x

Darriba, D., Taboada, G.L., Doallo, R., Posada, D., 2012, 'jModelTest 2: More models, new heuristics and parallel computing', Nature Methods 9(8), 772. https://doi. org/10.1038/nmeth.2109

Gunther, A. C., 1861, Catalogue of Acanthopterygian fishes in the British Museum 3. Addenda et Corrigenda, Trustees of the British Museum, London.

Hughes, J.M., Schmidt, D.J. \& Finn, D.S., 2009, 'Genes in streams: Using DNA to understand the movement of freshwater fauna and their riverine habitat', BioScience 59(7), 573-583. https://doi.org/10.1525/bio.2009.59.7.8

Kimura, M., 1981, 'Estimation of evolutionary distances between homologous nucleotide sequences', Proceedings of the National Academy of Sciences USA 78(1), 454-458. https://doi.org/10.1073/pnas.78.1.454

Larkin, M.A., Blackshields, G., Brown, N.P., Chenna, R., Mcgettigan, P.A., Mcwilliam, H. et al., 2007, 'Clustal W and Clustal X version 2.0', Bioinformatics 23(21), 2947-2948. https://doi.org/10.1093/bioinformatics/btm404

Maake, P.A., Gon, O. \& Swartz, E.R., 2014, 'Descriptions of three new species of Marcusenius Gill, 1862 (Teleostei: Mormyridae) from South Africa and Mozambique', Zootaxa 3780(3), 455-480. https://doi.org/10.11646/zootaxa.3780.3.2

Miller, M.A., Pfeiffer, W. \& Schwartz, T., 2010, 'Creating the CIPRES Science Gateway for inference of large phylogenetic trees', in Proceedings of the Gateway Computing Environments Workshop (GCE), New Orleans, LA, pp. 1-8.

Moritz, C., 1994, 'Defining 'evolutionary significant units' for conservation', Trends in Ecology \& Evolution 9(10), 373-375. https://doi.org/10.1016/0169-5347(94)90057-4

Nel, J.L., Driver, A., Strydom, W.F., Maherry, A., Petersen, C., Hill, L. et al., 2011, 'Atlas of freshwater ecosystem priority areas in South Africa: maps to support sustainable development of water resources', WRC Report NO. TT 500/11, Water Research Commission, Gezina, South Africa

Palumbi, S.R., 1996, 'Nucleic acids II: The polymerase chain reaction', in D.M. Hillis, C. Moritz \& B.K. Mable (eds.), Molecular systematics, pp. 205-247, Sinauer Associates, Inc, Sunderland, Massachusetts.
Pavlova, A., Beheregaray, L.B., Coleman, R., Gilligan, D., Harrisson, K.A., Ingram, B.A et al., 2017, 'Severe consequences of habitat fragmentation on genetic diversity of an endangered Australian freshwater fish: A call for assisted gene flow', Evolutionary Applications 10(6), 531-550. https://doi.org/10.1111/eva.12484

Puillandre, N., Modica, M.V., Zhang, Y., Sirovich, L., Boisselier, M.C., Cruaud, C. et al., 2012, 'Large-scale species delimitation method for hyperdiverse groups', MolecularEcology21(11), 2671-2691. https://doi.org/10.1111/j.1365-294X.2012. 05559.x

Roos, H., 2005, 'Genetic diversity in the anabantids Sandelia capensis and Sandelia bainsii: A phylogeography and phylogenetic investigation', MSc thesis, University of Pretoria, South Africa.

Ruane, S. \& Austin, C.C., 2017, 'Phylogenomics using formalin-fixed and 100+ year-old intractable natural history specimens', Molecular Ecology Resources 17(5), 1003-1008. https://doi.org/10.1111/1755-0998.12655

Rüber, L., Britz, R. \& Zardoya, R., 2006, 'Molecular phylogenetics and evolutionary diversification of labyrinth fishes (Perciformes: Anabantoidei)', Systematic Biology 55(3), 374-397. https://doi.org/10.1080/10635150500541664

Skelton, P.H., 2001, A complete guide to freshwater fishes of southern Africa, Southern Book Publishers Pty Ltd., JLB Smith Institute of Ichthyology, Grahamstown.

Skelton, P.H., 2018, 'Sir Andrew Smith - his contributions and connections to freshwater ichthyology in southern Africa', Transactions of the Royal Society of South Africa, 73(1), 42-55. https://doi.org/10.1080/0035919X.2017.1383322

Stamatakis, A., 2014, 'RAxML version 8: A tool for phylogenetic analysis and postanalysis of large phylogenies' Bioinformatics 30(9), 1312-1313. https://doi. org/10.1093/bioinformatics/btu033

Sunnucks, P. \& Hales, D.F., 1996, 'Numerous transposed sequences of mitochondria cytochrome oxidase I-II in aphids of the genus Sitobion (Hemiptera: Aphididae)' Molecular Biology and Evolution 13(3), 510-524. https://doi.org/10.1093/ Molecular Biology and Evolutior

Swartz, E.R., Skelton, P.H. \& Bloomer, P., 2009, 'Phylogeny and biogeography of the genus Pseudobarbus (Cyprinidae): Shedding light on the drainage history of rivers associated with the Cape Floristic Region', Molecular Phylogenetics and Evolution 51(1), 75-84. https://doi.org/10.1016/j.ympev.2008.10.017

Swofford, D.L., 2002, PAUP*, Phylogenetic analysis using parsimony (*and other methods), version 4, Sinauer Associates, Sunderland, MA.

Ward, R.D., 2009, 'DNA barcode divergence among species and genera of birds and fishes', Molecular Ecology Resources 9(4), 1077-1085. https://doi.org/10.1111/ j.1755-0998.2009.02541.x

Wishart, M., Hughes, J., Stewart, B. \& Impson, D., 2006, 'Extreme levels of intraspecific divergence among Cape Peninsula populations of the Cape galaxias, Galaxias zebratus Castelnau 1861, reveals a possible species complex African Journal of Aquatic Science 31(1), 99-106. https://doi.org/10.2989/ 16085910609503876 